Open Access

\title{
Erratum: Elevated basal levels of circulating activated platelets predict ICU-acquired sepsis and mortality: a prospective study
}

\author{
N. Layios ${ }^{1,2,3^{*}+}$, C. Delierneux ${ }^{2 \dagger}$, A. Hego ${ }^{2}$, J. Huart ${ }^{2}$, A. Joly ${ }^{4}$, P. Geurts ${ }^{4}$, P. Damas ${ }^{1}$, C. Lecut ${ }^{2,5}$, A. Gothot Got $^{2,5 \dagger}$ \\ and C. Oury ${ }^{2+}$
}

\section{Erratum}

After publication of our recent Poster presentation [1], we noticed that C. Delierneux, A. Hego, J Huart, A Joly, P Geurts, P Damas, C Lecut, A Gothot and C Oury had been inadvertently omitted as co-authors. The author list is now complete and the competing interests section modified accordingly.

\section{Competing interests}

The authors declare that they have no competing interests.

\section{Author details}

'Department of General Intensive Care, University Hospital Centre of Liège, Domaine Sart-Tilman B35, 4000 Liège, Belgium. ${ }^{2}$ GIGA-Cardiovascular Sciences, Laboratory of Thrombosis and Hemostasis, University of Liège, Domaine Sart-Tilman B35, 4000 Liège, Belgium. ${ }^{3} \mathrm{CHU}$ de Liège, Domaine Sart-Tilman B35, 4000 Liège, Belgium. ${ }^{4}$ Systems and Modeling, Department of Electrical Engineering and Computer Science and GIGA-R, University of Liège, Domaine Sart-Tilman B35, 4000 Liège, Belgium. ${ }^{5}$ Laboratory Hematology, University Hospital Centre of Liège, Liège, Belgium.
Published online: 26 August 2015

\section{Reference}

1. Layios N. Elevated basal levels of circulating activated platelets predict ICU-acquired sepsis and mortality: a prospective study. Crit Care. 2015;19 (Suppl 1):P29.
* Correspondence: nathalie.layios@chu.ulg.ac.be

${ }^{\dagger}$ Equal contributors

'Department of General Intensive Care, University Hospital Centre of Liège, Domaine Sart-Tilman B35, 4000 Liège, Belgium

${ }^{2}$ GIGA-Cardiovascular Sciences, Laboratory of Thrombosis and Hemostasis, University of Liège, Domaine Sart-Tilman B35, 4000 Liège, Belgium Full list of author information is available at the end of the article

\section{Submit your next manuscript to BioMed Central} and take full advantage of:

- Convenient online submission

- Thorough peer review

- No space constraints or color figure charges

- Immediate publication on acceptance

- Inclusion in PubMed, CAS, Scopus and Google Scholar

- Research which is freely available for redistribution

Submit your manuscript at www.biomedcentral.com/submit 